\title{
Predominance of D2 Receptors in Mediating Dopamine's Effects in Brain Metabolism: Effects of Alcoholism
}

\author{
Nora D. Volkow, ${ }^{1,2}$ Dardo Tomasi, ${ }^{2}$ Gene-Jack Wang, ${ }^{3}$ Frank Telang, ${ }^{1}$ Joanna S. Fowler, ${ }^{3}$ Jean Logan, ${ }^{3}$ L. Jayne Maynard, ${ }^{1}$ \\ and Christopher T. Wong ${ }^{1}$ \\ ${ }^{1}$ National Institute of Drug Abuse and ${ }^{2}$ National Institute of Alcohol Abuse and Alcoholism, Rockville, Maryland 20857, and ${ }^{3}$ Medical and Chemistry \\ Departments, Brookhaven National Laboratory, Upton, New York 11973
}

\begin{abstract}
Dopamine signals through D1-like and D2-like receptors, which can stimulate or inhibit, respectively, neuronal activity. Here we assessed the balance between D1 or D2 receptor signaling in the human brain and how it is affected in alcoholism. Using PET, we measured the relationship between changes in dopamine and brain glucose metabolism induced by methylphenidate in controls and alcoholics. We show that methylphenidate induced significant DA increases in striatum, amygdala, and medial orbitofrontal cortex, whereas it decreased metabolism in these brain regions. Methylphenidate-induced dopamine increases were greater in controls than in alcoholics, whereas methylphenidate-induced metabolic decreases were greater in alcoholics. For both groups, methylphenidate-induced dopamine increases were associated with decreases in regional brain metabolism, and the correlations were strongest in subthalamic nuclei, anterior cingulate, and medial orbitofrontal cortex. These correlations were more extensive and robust and the slopes steeper in alcoholics than in controls despite their attenuated dopamine responses to methylphenidate, which suggests an impaired modulation of dopamine signals in the brain of alcoholic subjects. These findings are consistent with a predominant inhibitory effect of dopamine in the human brain that is likely mediated by the prominence of dopamine D2/D3 receptors.
\end{abstract}

\section{Introduction}

Dopamine (DA) signals via D1-like (D1, D5) and D2-like (D2, D3, D4) receptors, which have opposite effects at the cellular level, stimulating or inhibiting, respectively, adenylate cyclase (Girault and Greengard, 2004). Thus, by differentially affecting D1-like versus D2-like receptors, DA can activate or inhibit regional brain activity.

Drugs of abuse, which stimulate brain DA signaling (Koob and Bloom, 1988), could therefore result in activation or inhibition of target regions of the mesolimbic and mesocortical DA pathways, depending on the predominance of D1-like versus D2like receptors. Interestingly, whereas in rats cocaine predominantly increases regional activity in striatum and cortical regions, in humans and nonhuman primates it predominantly decreases their activity (for review, see Mandeville et al., 2011). This discrepancy was interpreted as reflecting a predominance of the inhibitory effects of D2 receptors (D2R) in humans and nonhuman primates and a predominance of the stimulatory effects of D1 receptors (D1R) in rats (Mandeville et al., 2011). Here we test the hypothesis that in the human brain there is a predominance of D2R and thus drug-induced DA increases should predomi-

Received Nov. 13, 2012; revised Dec. 23, 2012; accepted Jan. 24, 2013.

Author contributions: N.D.V. and G.-J.W. designed research; N.D.V., D.T., G.-J.W., F.T., J.S.F., J.L., L.J.M., and C.T.W. performed research; N.D.V. and D.T. analyzed data; N.D.V. wrote the paper.

This research was supported by the National Institutes of Health intramural program.

The authors declare no competing financial interests.

Correspondence should be addressed to Dr. Nora D. Volkow, National Institute of Drug Abuse, Executive Boulevard 6001, Room 5274, Rockville, MD 20857. E-mail: nvolkow@nida.nih.gov.

DOI:10.1523/JNEUROSCI.5261-12.2013

Copyright $\odot 2013$ the authors $\quad 0270-6474 / 13 / 334527-09 \$ 15.00 / 0$ nantly decrease regional brain activity. Also, because drug addiction impairs DA signaling (Volkow et al., 2012), we also hypothesized that the responses of the brain to DA stimulation would be disrupted in alcoholic subjects.

For this purpose, we measured the effects of intravenous methylphenidate (MP) on DA and on regional brain glucose metabolism in controls and in detoxified alcoholics. PET imaging with $\left[{ }^{11} \mathrm{C}\right]$ raclopride (radioligand that binds to DA D2/D3 receptors that are not occupied by endogenous DA) was used to measure MP-induced changes in DA by comparing radiotracer binding between placebo and MP conditions (Volkow et al., 1994), while $\left[{ }^{18} \mathrm{~F}\right]$ deoxyglucose (FDG) was used to measure the effects of MP (compared with placebo) on brain glucose metabolism (marker of brain function) (Sokoloff et al., 1977). Thus, each subject underwent two sets of paired scans in which a $\left[{ }^{11} \mathrm{C}\right]$ raclopride scan was followed 90 min later by an FDG scan: on one day, the set was done after placebo; and on another day, it was done after intravenous MP (Fig. 1). MP blocks the DA transporters (Volkow et al., 1998), thus increasing DA in the human brain (Volkow et al., 2002). We previously reported the comparison of the striatal DA increases induced by MP between controls and alcoholics and showed that alcoholics had reduced responses (Volkow et al., 2007a). Here, we extend those studies to assess, for the first time, the relationship between the MP-induced changes in DA and the concomitant changes in regional brain glucose metabolism, which serves as a marker of brain activity. We also compare the relationship between MP-induced changes in DA and regional brain metabolism between controls and alcoholics. We hypothesized that DA stimulation of DA D2/D3 receptors, which are inhibitory (West and Grace, 2002), would be associated 


\section{Placebo MP $(0.5 \mathrm{mg} / \mathrm{kg})$}
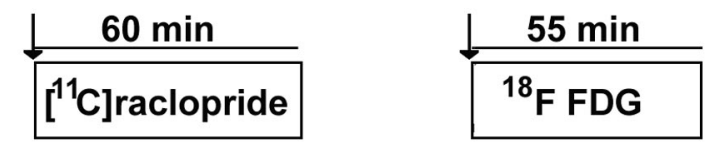

\section{$90 \mathrm{~min}$}

Figure 1. Diagram of the experimental design. Subjects were tested on two separate days. On each day, they were scanned first with $\left[{ }^{11} \mathrm{C}\right]$ raclopride, and this was followed by an FDG scan. On one of the days, the subjects received intravenous placebo (saline solution); and on the other day, they received intravenous MP, which was given $5 \mathrm{~min}$ before $\left[{ }^{11} \mathrm{C}\right]$ raclopride injection.

with decreases in regional metabolism. We also hypothesized that alcoholics would show stronger associations as a result of impairments in their ability to modulate the large increases in DA triggered by intravenous MP.

\section{Materials and Methods}

Subjects. Twenty male alcoholics and 20 male healthy controls were recruited, and the four imaging studies (two FDG and two $\left[{ }^{11} \mathrm{C}\right]$ raclopride) were completed in 17 alcoholics ( $41 \pm 6$ years old, $13 \pm 2$ years of education, 14 cigarette smokers) and in 19 of the healthy controls (41 \pm 6 years old, $14 \pm 2$ years of education, 2 cigarette smokers). Alcoholics were recruited from therapeutic communities and advertisements (mean $23 \pm 10$ years of alcohol abuse, daily alcohol use of $16 \pm 8$ beer equivalent and had discontinued alcohol for at least $30 \mathrm{~d}$ with a range $30-164 \mathrm{~d}$ ). At least two clinicians interviewed the patients to ensure that they met DSM-IV diagnostic criteria for alcoholism, with a semistructured standardized interview. Inclusion criteria also required that they had a firstdegree relative who was an alcoholic. Subjects were excluded if they had a history of substance abuse or addiction (other than alcohol and nicotine). Exclusion criteria also included history of psychiatric disease (other than alcohol dependence), or neurological disease, medical conditions that may alter cerebral function (i.e., cardiovascular, endocrinological, oncological, or autoimmune diseases), current use of prescribed or overthe-counter medications, and/or head trauma with loss of consciousness of $>30 \mathrm{~min}$. All subjects had Hamilton's Anxiety and Depression scores (Hamilton, 1960) $<19$ and had to have refrained from drinking alcohol at least $30 \mathrm{~d}$ before the study. Controls were recruited from advertisements in local newspapers; exclusion criteria other than allowance for alcohol dependence or abuse were the same as for alcoholic subjects. In addition, control subjects were excluded if they had a family history of alcoholism. All subjects had a physical, psychiatric, and neurologic examination. Drug screens were done on the days of the PET studies to exclude the use of psychoactive drugs. Subjects were instructed to discontinue any over-the-counter medication 2 weeks before the PET scan and controls to refrain from drinking alcohol the week before the PET scan. Food and beverages (except for water) were discontinued at least $4 \mathrm{~h}$ before and cigarettes for at least $2 \mathrm{~h}$ before the study. This study was approved by the Committee on Research in Human Subjects at Brookhaven National Laboratory and at Stony Brook University, and written informed consent was obtained from all subjects.

Behavioral and cardiovascular measures. Subjective ratings for drug effects were recorded before and 27, 57, 90, 130, and 150 min after placebo or MP administration (1-10) (Wang et al., 1997). Heart rate and blood pressure were monitored before and periodically after placebo or MP administration. MP concentration in plasma was measured using capillary GC/mass spectrometry (Srinivas et al., 1991). A factorial repeated ANOVA was used to assess the effects of MP in the behavioral measures (drug main effect) and to assess whether the differences differed between controls and addicted subjects (drug $\times$ group interaction effect).

Scans. PET studies were done with a Siemens HR+ tomograph (resolution $4.5 \times 4.5 \times 4.5 \mathrm{~mm}$ full width half-maximum) in 3D mode. Each subject underwent two PET $\left[{ }^{11} \mathrm{C}\right]$ raclopride and two PET FDG scans done on two separate days. On a given day, each subject was injected first with $\left[{ }^{11} \mathrm{C}\right]$ raclopride and then 90 min later with FDG. Five minutes before injection of $\left[{ }^{11} \mathrm{C}\right]$ raclopride, subjects were injected with a placebo ( $3 \mathrm{ml}$ saline i.v.) on one day and with MP $(0.5 \mathrm{mg} / \mathrm{kg}$ i.v. $)$ on another day. The order of administration was randomized. The study was a singleblind design (subjects were blind to the drugs received). For $\left[{ }^{11} \mathrm{C}\right]$ raclopride, dynamic scans were started immediately after injection of 4-10 $\mathrm{mCi}$ of $\left[{ }^{11} \mathrm{C}\right]$ raclopride (specific activity $0.5-1.5 \mathrm{Ci} / \mu \mathrm{M}$ at end of bombardment) for a total of $60 \mathrm{~min}$ using previously published procedures (Volkow et al., 1993b). For FDG, an emission scan was obtained for 20 min and was started $35 \mathrm{~min}$ after injection of $4-6 \mathrm{mCi}$ of FDG using previously described procedures (Wang et al., 1993). Blood sampling was obtained from a catheter placed in the radial artery, which was used to measure the concentration of radiotracer in plasma. During the uptake period of FDG and during the $\left[{ }^{11} \mathrm{C}\right]$ raclopride scanning period, subjects remained in a supine position with their eyes open in a darkly lit room, and noise was kept to a minimum, except for the periodic assessment of drug effects. Metabolic rates were computed using an extension of Sokoloff's model (Phelps et al., 1979) (for experimental design, see Fig. 1).

Analysis. The data for the $\left[{ }^{11} \mathrm{C}\right]$ raclopride images (transformed to nondisplaceable binding potential or $\mathrm{BP}_{\mathrm{ND}}$ ) and for the metabolic images (normalized to whole-brain metabolism) were analyzed using the Statistical Parametric Mapping (SPM) (Friston et al., 1995) package SPM2 (Wellcome Trust Centre for Neuroimaging). Specifically, the PET images were spatially normalized to the stereotactic space of the MNI using a 12-parameter affine transformation. The SPM2 FDG template (PET.mnc) was used to normalize the metabolic images, which were then normalized to their mean signal intensity. For the $\left[{ }^{11} \mathrm{C}\right]$ raclopride images, we estimated for each voxel, the distribution volume (DV), which corresponds to the equilibrium measurement of the ratio of the radiotracer's tissue concentration to that of its plasma concentration using a graphical analysis technique for reversible systems (Logan et al., 1990). A custom MNI template, which was previously developed using DV images from 34 healthy subjects that were acquired with $\left[{ }^{11} \mathrm{C}\right]$ raclopride and the same PET scanning sequence (Wang et al., 2011), was used for the spatial normalization of the DV images. Then, the intensity of the DV images was normalized to that in the cerebellum (left and right ROI) to obtain images of the DV ratios, which correspond to the nondisplaceable binding potential $\left(\mathrm{BP}_{\mathrm{ND}}\right)$ in each voxel. The normalized metabolic and $\mathrm{BP}_{\mathrm{ND}}$ images were then spatially smoothed using an $8 \mathrm{~mm}$ Gaussian kernel to minimize the variability of the brain anatomy across subjects.

Statistical group analyses were based on a factorial repeated ANOVA SPM2 model with two groups (alcoholics and controls) and two conditions (MP-placebo). A mask of a priori selected regions (dorsal and ventral striatum, amygdala, and orbitofrontal cortex [OFC]) was created using the digital anatomical brain atlases provided with the MRIcro software (http://www.cabiatl.com/mricro/). Specifically, the voxels corresponding to the amygdala and striatum (caudate, putamen, and globus pallidus) were defined in the MNI stereotactic space using the Automated Anatomical Labeling atlas, whereas those for the cortical regions were computed using the Brodmann atlas (Van Essen et al., 2011). The statistical significance of group differences on differential regional brain metabolism and $\mathrm{BP}_{\mathrm{ND}}$ (MP-placebo) within the mask of a priori selected regions was set by a voxel-level threshold $p_{\mathrm{FWE}}<0.05$, corrected for multiple comparisons with the familywise error rate and small volume corrections (10-mm-diameter spherical searching volume) in SPM2. Simple regression analyses in SPM2 were used to access the voxelwise correlations across subjects between the changes induced by MP on $\mathrm{BP}_{\mathrm{ND}}\left(\Delta \mathrm{BP}_{\mathrm{ND}}\right)$ and the changes on metabolism $(\Delta \mathrm{FDG})$, separately for controls and alcoholics. For this purpose, we used the Biological Parametric Mapping, a toolbox for SPM2 that allows voxelwise statistical analyses of multimodality imaging datasets (Casanova et al., 2007), and a conservative statistical significance threshold ( $p<0.001,100$ voxels).

ROI analyses were conducted to assess the differences in the regressions of $\triangle \mathrm{BP}_{\mathrm{ND}}$ to $\triangle \mathrm{FDG}$ between controls and alcoholics. Specifically, the average intensity of the FDG and $\mathrm{BP}_{\mathrm{ND}}$ images was extracted from $10 \mathrm{~mm}$ isotropic ROIs (125 voxels) centered at the cluster maxima identified by the SPM analysis and were kept fixed across subjects. 

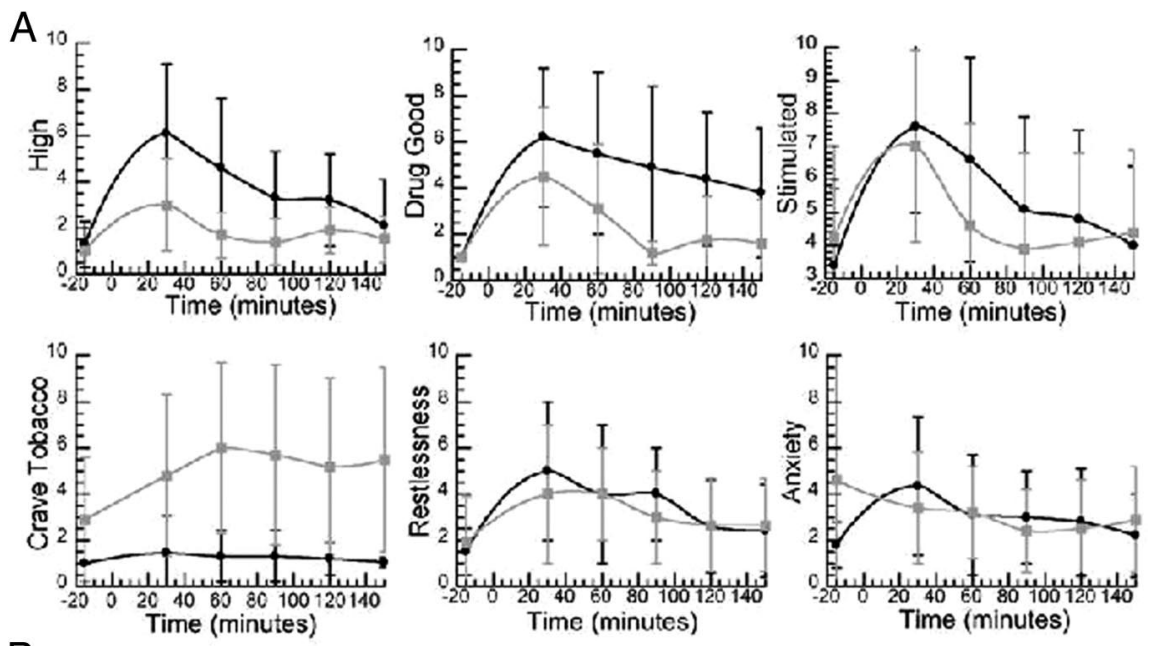

$\mathrm{B}$
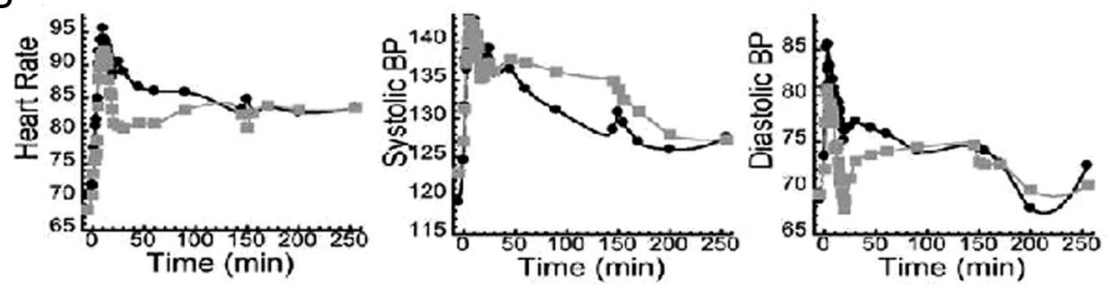

Figure 2. Behavioral $(\boldsymbol{A})$ and cardiovascular $(\boldsymbol{B})$ effects of MP in controls (black symbols) and alcoholics (gray symbols). $\boldsymbol{A}$ Self-reports of drug effects, high, and stimulated were significantly larger in controls than in alcoholics $(p<0.05)$. Cardiovascular effects did not differ between groups.

We used linear bivariate regression (two groups, difference between slopes or intercepts) using the Primer of Biostatistics 4.02 software package (Glantz, 2002; Casanova et al., 2007), to test the null hypothesis for the differences in slope and intercept of the regression lines between alcoholics and controls. Statistical significance was set at $p<$ 0.005 to partially account for the multiple comparisons in these ROI analyses.

The ROI measures were also used to assess the correlations between changes in metabolism in the regions where MP-induced significant changes and MP's behavioral effects using Pearson's product moment correlation analysis. Statistical significance was set at $p<0.006$ to partially account for multiple comparisons (per Bonferroni for 8 behavioral measures $0.05 / 8=0.006$ ).

\section{Results}

\section{Behavioral and cardiovascular effects of MP and MP plasma concentration}

MP's behavioral effects were higher for controls than alcoholics for "high" (ANOVA: group, $p=0.0003$; drug, $F=30, p<0.0001$; interaction, $F=7, p=0.0001$ ); "drug good" (group, $F=14, p=$ 0.0006; drug, $F=24, p<0.0001$; interaction, $F=4, p=0.002$ ); and for "stimulated," the effects were longer lasting in controls than alcoholics (group, not significant; drug, $F=23, p=0.0001$; interaction, $F=4, p=0.002$ ). Increases in "restlessness" were similar for both groups (group, not significant; drug, $F=16, p=$ 0.0001 ; interaction, not significant); for "anxiety," it trended toward increases in controls and decreases in alcoholics (group, not significant; drug, not significant; interaction, $F=2.5, p=0.04$ ); and MP increased "nicotine craving" in alcoholics but not in controls (group, $F=27, p<0.0001$; drug, $F=6.5, p<0.0001$; interaction, $F=5, p=0.0004$ ) (Fig. $2 A$ ).

At the end of the study, subjects were asked to rate "drug liking" (0-10), which was higher for controls $(6.2 \pm 3)$ than alcoholics (4 \pm 3$)$ and "drug disliking," which was higher for alcoholics $(6.6 \pm 3)$ than controls $(3.8 \pm 3)(p=0.005)$.

MP increased heart rate and systolic and diastolic blood pressure, but the effects did not differ between controls and alcoholics (Fig. 2B).

Serum concentrations of MP at 15 and 60 min after injection, respectively, were for the controls $116 \pm 26$ and $52 \pm 11$ $\mathrm{ng} / \mathrm{ml}$; and for the alcoholics $107 \pm 16$ and $48 \pm 9 \mathrm{ng} / \mathrm{ml}$; these values did not differ between the groups.

\section{Effects of MP on brain DA measured with $\left[{ }^{11} \mathrm{C}\right]$ raclopride}

Statistical parametic analysis (SPM) revealed significant decreases in the nonspecific binding potential $\left(\mathrm{BP}_{\mathrm{ND}}\right)$ of $\left[{ }^{11} \mathrm{C}\right]$ raclopride with MP (reflecting DA increases) in striatum, amygdala, and medial OFC or OFC (BA 11 and BA 25) both in controls and alcoholics (Fig. 3; Table 1).

Comparisons of the $\Delta$ images for the contrast controls $>$ alcoholics $\left(p_{\mathrm{cFWE}}<\right.$ 0.05 ) showed significant differences in putamen/globus pallidum $(-16,2,6)$, indicating that the effects of $\mathrm{MP}$ in $\mathrm{BP}_{\mathrm{ND}}$ were greater in controls than in alcoholics (Fig. $3)$. There were no significant differences for the contrast alcoholics $>$ controls.

The correlation between smoking histories (number of cigarettes and years of smoking in the alcoholics; 14 of the 17 alcoholics were smokers) and MP-induced changes in $\mathrm{BP}_{\mathrm{ND}}$ was not significant.

\section{Effects of MP on brain metabolism measured with FDG}

MP did not change whole-brain glucose metabolism in controls (placebo: $36.4 \pm 5$ vs MP: $38.0 \pm 9 \mu \mathrm{mol} / \mathrm{g} / \mathrm{min} ; 5 \pm 22 \%$ increase, not significant) or in alcoholics (placebo: $35.5 \pm 5$ vs MP: $34.2 \pm 5 \mu \mathrm{mol} / \mathrm{g} / \mathrm{min}, F=2.5, p=0.13 ; 3 \pm 10 \%$ decrease, not significant).

Brain metabolic images were normalized to the individual's whole-brain metabolism to accentuate regional effects. The SPM analyses on these normalized images showed that MP significantly increased metabolism in cerebellum in both groups; and in controls, it also increased activity in lateral OFC, right thalamus (including habenula), and inferior temporal pole (BA 38); and in alcoholics, it also increased activity in midbrain (Fig. 4; Tables 2 and 3). The SPM also showed that MP-induced decreases in metabolism in striatum, medial prefrontal (including medial OFC), and occipital cortices (Fig. 4; Tables 2 and 3).

Comparison of the $\Delta$ images (MP-placebo) between controls and alcoholics $\left(p_{\mathrm{cFWE}}<0.05\right)$ showed that the decreases in metabolism were significantly larger in alcoholics than in controls in amygdala $(-26,-2,-16)$, OFC $(-6,60,-24)$, and caudate/ ventral striatum $(-12,20,-2)$ (Fig. 5). There were no differences in MP-induced increases in relative metabolism between groups.

The SPM analysis for the correlation between smoking histories (number of cigarettes and years of smoking) in the alcoholics 

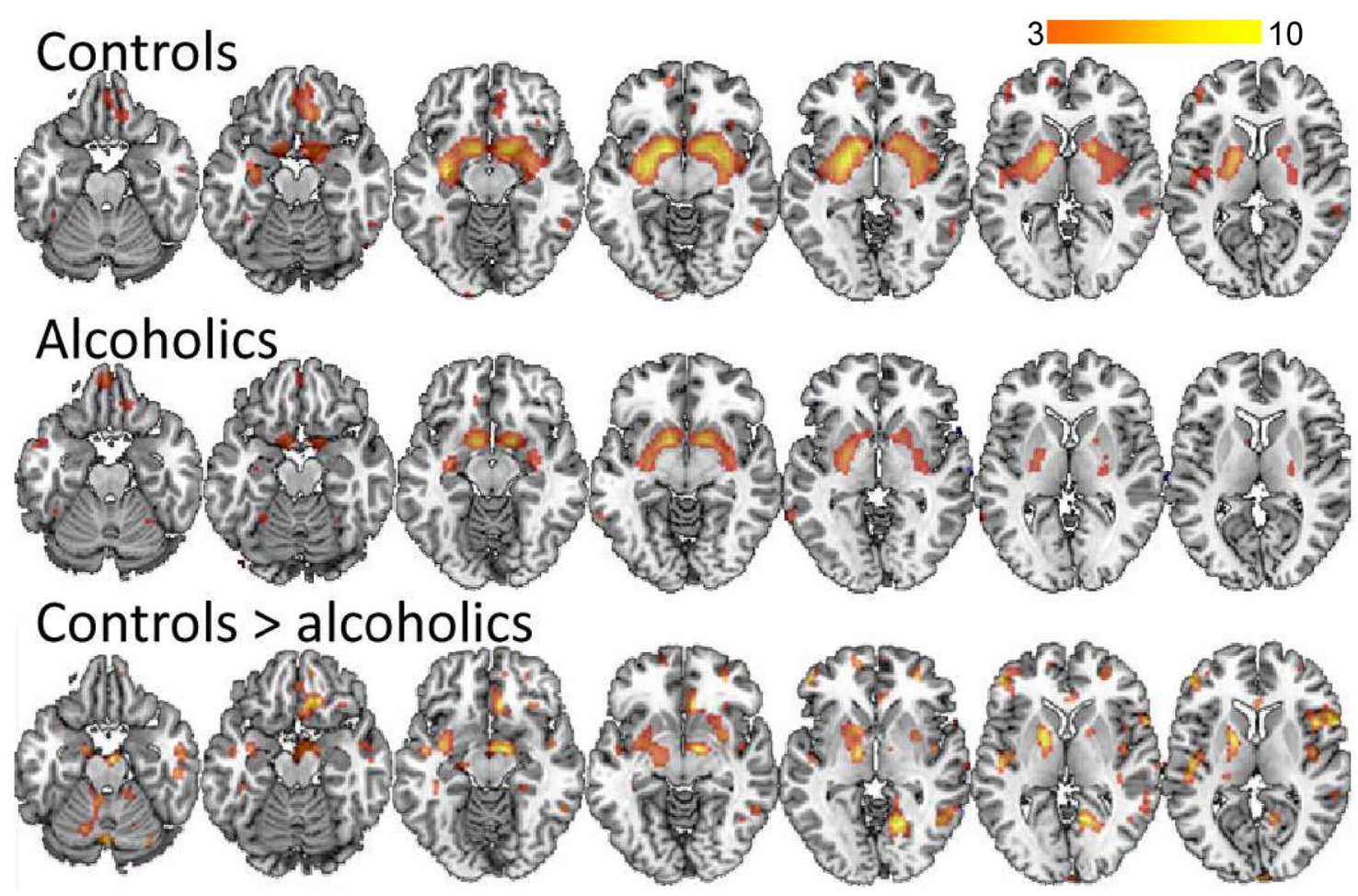

Figure 3. SPM results for the comparison of MP versus placebo on the $\mathrm{BP}_{\mathrm{ND}}$ images from $\left[{ }^{11} \mathrm{C}\right]$ raclopride in the controls and in the alcoholic subjects $\left(p_{\mathrm{u}}<0.005\right)$. The regions shown are those where $M P$ decreased $\mathrm{BP}_{\mathrm{ND}}$, which correspond to the regions where MP increased DA. The contrast controls $>$ alcoholics indicates that $\mathrm{MP}$ induced greater decreases in $\mathrm{BP} \mathrm{ND}_{\mathrm{ND}}$ (reflecting greater $\mathrm{DA}$ increases) in the controls than in the alcoholics. There were no regions where alcoholics showed greater $\mathrm{BP}_{\mathrm{ND}}$ decreases than the controls. The color scale indicates the $t$ values for the comparisons.

Table 1. Location of regions where $B P_{\mathrm{ND}}(\mathrm{D} 2 / \mathrm{D} 3$ receptor availability) was significantly decreased by MP in controls and in alcoholics $\left(p_{\mathrm{FWE}}{ }^{-c o r r e c t e d}=0.05\right.$, small volume correction) ${ }^{a}$

\begin{tabular}{lccrrr}
\hline Region & Cluster & $t$ & $x$ & $y$ & \multicolumn{1}{c}{$z$} \\
\hline $\begin{array}{l}\text { Controls } \\
\quad\end{array}$ & & & & & \\
$\quad$ L striatum & 6620 & 9.1 & -30 & 2 & -6 \\
R striatum & & & -22 & -2 & -4 \\
R medial prefrontal & 316 & 5.4 & 12 & 56 & -2 \\
& & & 14 & 60 & 14 \\
L orbitofrontal & 831 & 4.6 & -14 & 32 & -18 \\
& & & 0 & 46 & -18 \\
L temporal & 323 & 4.3 & -60 & -40 & 6 \\
R prefrontal & 439 & 4.1 & 38 & 48 & 28 \\
$\quad$ L orbitofrontal & 110 & 3.8 & -38 & 26 & -10 \\
Alcoholics & & & & & \\
$\quad$ R striatum & 2814 & 7.4 & 10 & 6 & -10 \\
L striatum & & & -16 & 6 & 10 \\
$\quad$ R orbitofrontal & 232 & 4.7 & 2 & 52 & -22 \\
R temporal & 187 & 4.6 & 66 & -50 & -2 \\
$\quad$ L orbitofrontal & 154 & 3.3 & -14 & 32 & -22 \\
\hline
\end{tabular}

${ }^{a} \mathrm{MNI}$ coordinates ( $x$, right left; $y$, anterior posterior; $z$, superior inferior) along with volume of the cluster (in voxels) and the $t$ values for the comparisons.

$L$, Left; $R$, right.

and MP-induced changes in regional brain metabolism revealed that it was not significant.

\section{Correlations between MP-induced changes in DA and in brain metabolism}

A voxelwise correlation analysis with SPM showed significant positive correlations $\left(p_{\mathrm{FWE}}<0.05\right)$ both in controls and alcoholics, such that MP-induced decreases in $\mathrm{BP}_{\mathrm{ND}}$ (reflecting DA increase) were associated with decreases in relative metabolism (Fig. 5). Thus, the greater the DA increases, the larger the relative decreases in metabolism. Across both groups, the strongest correlations occurred in subthalamic nuclei, locus ceruleus, anterior cingulate cortex (ACC), rectal gyrus, and parahippocampal gyrus. In cortical regions, the correlations in the alcoholics were stronger and more extensive than in controls (Fig. 5; Tables 4 and 5).

Comparisons of the correlations between controls and alcoholics showed that these were significantly stronger and the regression slopes steeper for alcoholics than controls in inferior frontal cortex, superior frontal cortex, OFC, ACC, lingual and fusiform cortices, parahippocampal cortex, and precuneus (Fig. 6; Table 6). None of the correlations was stronger in controls than in alcoholics.

The correlation between MP-induced changes in metabolism and its behavioral effects was not significant.

\section{Discussion}

Here we show that MP induced DA increases in striatum, amygdala, and medial OFC, whereas it decreased metabolism in these regions. We also show a positive correlation between MPinduced $\mathrm{BP}_{\mathrm{ND}}$ and FDG changes, such that DA increases were associated with decreases in regional glucose metabolism (normalized to whole-brain). These correlations were significantly stronger and the slopes were steeper in alcoholics than controls.

\section{MP-induced DA increases}

We showed that MP increased DA, as evidenced by decreases in $\mathrm{BP}_{\mathrm{ND}}$, which were significant in striatum (including pallidum), amygdala, and medial OFC. Multiple studies had reported reproducible decreases in striatal $\mathrm{BP}_{\mathrm{ND}}$ after stimulant (MP and amphetamine) administration using $\left[{ }^{11} \mathrm{C}\right]$ raclopride as well as other PET D2R radiotracers (Wang et al., 1999; Shotbolt et al., 2011); our findings are consistent with such studies. A few studies have 


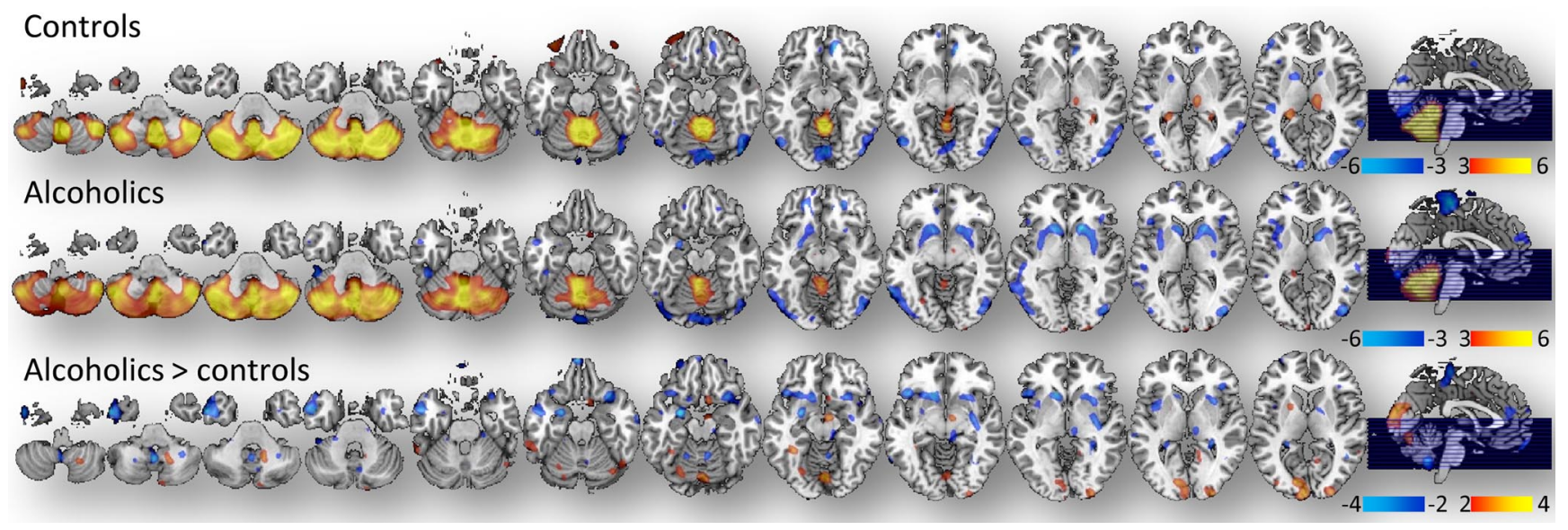

Figure 4. SPM results for the comparison of MP versus placebo on the relative metabolic images in the controls and in the alcoholic subjects $\left(p_{u}<0.005\right)$. The contrast shows the regions where MP increased metabolism (yellow/red) and where it decreased metabolism (blue). The contrast alcoholic $>$ controls indicates the regions where MP induced greater decreases in metabolism (blue) and greater increases in metabolism (red) in alcoholics than in the controls. The color scale indicates the $t$ values for the comparisons.

\begin{tabular}{|c|c|c|c|c|c|c|}
\hline Region & $B A$ & Cluster & $t$ & $x$ & $y$ & $z$ \\
\hline \multicolumn{7}{|l|}{ Increases } \\
\hline Cerebellum & & 14905 & 13.1 & $\begin{array}{r}2 \\
-2\end{array}$ & $\begin{array}{l}-54 \\
-46\end{array}$ & $\begin{array}{l}-40 \\
-18\end{array}$ \\
\hline L post-thalamus & & 230 & 4.9 & 24 & -30 & 6 \\
\hline L lateral OFC & 11,47 & 651 & 4.3 & $\begin{array}{l}-36 \\
-52\end{array}$ & $\begin{array}{l}48 \\
18\end{array}$ & $\begin{array}{r}-22 \\
-6\end{array}$ \\
\hline R hippocampal & 36 & 160 & 4.2 & 30 & -42 & 2 \\
\hline L temporal pole & 21,38 & 272 & 4.2 & -46 & 0 & -48 \\
\hline R lateral OFC & 11 & 293 & 3.9 & 30 & 60 & -18 \\
\hline \multicolumn{7}{|l|}{ Decreases } \\
\hline R medial frontal & 11 & 670 & 6.1 & 12 & 40 & -10 \\
\hline L medial frontal & 10,11 & 3462 & 5.6 & $\begin{array}{l}-42 \\
-28\end{array}$ & $\begin{array}{l}48 \\
16\end{array}$ & $\begin{array}{l}22 \\
62\end{array}$ \\
\hline Roccipital & 19 & 3299 & 5.1 & 46 & -80 & -18 \\
\hline Roccipital & 19 & 1291 & 5.0 & 4 & -80 & -14 \\
\hline R putamen & & 190 & 4.8 & 38 & 0 & 14 \\
\hline L insula & & 533 & 4.6 & -42 & -28 & 12 \\
\hline L temporal/parietal & 37,39 & 3342 & 4.6 & -50 & -70 & -10 \\
\hline L caudate & & 381 & 4.4 & -12 & 8 & 12 \\
\hline R postcentral & 40 & 107 & 3.9 & 44 & -36 & 38 \\
\hline R superior frontal & 8 & 102 & 3.7 & 28 & 18 & 56 \\
\hline R caudate & & 158 & 3.6 & 14 & 12 & 10 \\
\hline L medial OFC & 11 & 128 & 3.4 & -10 & 58 & -8 \\
\hline
\end{tabular}

${ }^{a} \mathrm{MNI}$ coordinates ( $x$, right left; $y$, anterior posterior; $z$, superior inferior) along with volume of the cluster (in voxels) and the $t$ values for the comparisons.

L, Left; R, right.

also reported decreases in $\mathrm{BP}_{\mathrm{ND}}$ in amygdala with $\left[{ }^{11} \mathrm{C}\right]$ raclopride after MP (Volkow et al., 2007b) and with other D2R PET radiotracers after amphetamine administration in humans (Riccardi et al., 2006; Slifstein et al., 2009) and in nonhuman primates (Mukherjee et al., 2005). Although to our knowledge this is the first report of $\mathrm{MP}$-induced $\mathrm{BP}_{\mathrm{ND}}$ decreases in OFC using $\left[{ }^{11} \mathrm{C}\right]$ raclopride, others had reported $\mathrm{BP}_{\mathrm{ND}}$ decreases in frontal cortex after amphetamine administration using other radiotracers (Narendran et al., 2009; Treadway et al., 2012). Thus, our findings and those from prior imaging studies suggest that stimulant drugs administered intravenously increase DA in striatum, amygdala, and OFC (however, see Limitations).
Table 3. Location of regions where metabolism was significantly increased or decreased by MP in alcoholics $\left(p_{\mathrm{FWE}}{ }^{- \text {corrected }}=\mathbf{0 . 0 5} \text {, small volume correction }\right)^{a}$

\begin{tabular}{|c|c|c|c|c|c|c|}
\hline Region & $B A$ & Cluster & $t$ & $x$ & $y$ & $z$ \\
\hline \multicolumn{7}{|l|}{ Increases } \\
\hline $\mathrm{R}$ cerebellum & & 15620 & 11.2 & 42 & -56 & -38 \\
\hline Roccipital & 17,18 & 112 & 4.2 & 22 & -104 & -4 \\
\hline L occipital & 17 & 260 & 4.1 & -2 & -104 & 2 \\
\hline L post-thalamus & & 125 & 3.9 & -20 & -32 & 14 \\
\hline \multirow[t]{2}{*}{ Midbrain } & & 175 & 3.4 & 10 & -10 & -6 \\
\hline & & & & -10 & -14 & -10 \\
\hline L occipital & 19 & 108 & 3.3 & -26 & -68 & -8 \\
\hline \multicolumn{7}{|l|}{ Decreases } \\
\hline R caudate/putamen & & 17495 & 5.8 & 18 & 18 & -2 \\
\hline L caudate/putamen & & & & -10 & 16 & 0 \\
\hline Paracentral/precuneus & 5,7 & & & -2 & -28 & 66 \\
\hline Roccipital & 19 & 1955 & 4.7 & 44 & -80 & 8 \\
\hline L occipital & 19 & 2749 & 4.7 & -62 & -58 & -6 \\
\hline R medial frontal & 10 & 176 & 4.4 & 26 & 48 & -10 \\
\hline L temporal pole & 20,21 & 319 & 4.4 & -44 & -34 & -32 \\
\hline L temporal pole & 21 & 315 & 3.6 & -56 & 0 & -40 \\
\hline Precuneus & 7 & 106 & 3.6 & -8 & -56 & 36 \\
\hline R medial temporal & 21 & 285 & 3.4 & 58 & -28 & 8 \\
\hline R precentral & 4,6 & 304 & 3.3 & 34 & -16 & 52 \\
\hline R precentral & 4,6 & 138 & 3.3 & 48 & -28 & 58 \\
\hline R precentral & 4,6 & 128 & 3.1 & 62 & -22 & 38 \\
\hline
\end{tabular}

${ }^{a} \mathrm{MNI}$ coordinates $(x$, right left; $y$, anterior posterior; $z$, superior inferior) along with volume of the cluster (in voxels) and the $t$ values for the comparisons.

L, Left; R, right.

MP-induced changes in brain activity

MP increased cerebellar metabolism, whereas it decreased relative metabolism in striatum, amygdala, and medial OFC. Interestingly, the regions with decreases in metabolism were the ones where MP induced significant DA increases (decreases in $\left[{ }^{11} \mathrm{C}\right]$ raclopride's $\mathrm{BP}_{\mathrm{ND}}$ ).

The results are consistent with our findings in healthy controls showing decreases in striatal metabolism (Volkow et al., 1997) and in cocaine abusers also in amygdala and medial OFC after intravenous MP administration (Volkow et al., 2003) and with studies in nonhuman primates showing that acute cocaine decreased glucose metabolism in striatum and limbic cortex (including OFC) (Lyons et al., 1996) and that it decreased cerebral blood volume in striatum and frontal cortex (Mandeville et al., 2011). They are also in agreement with fMRI studies reporting 


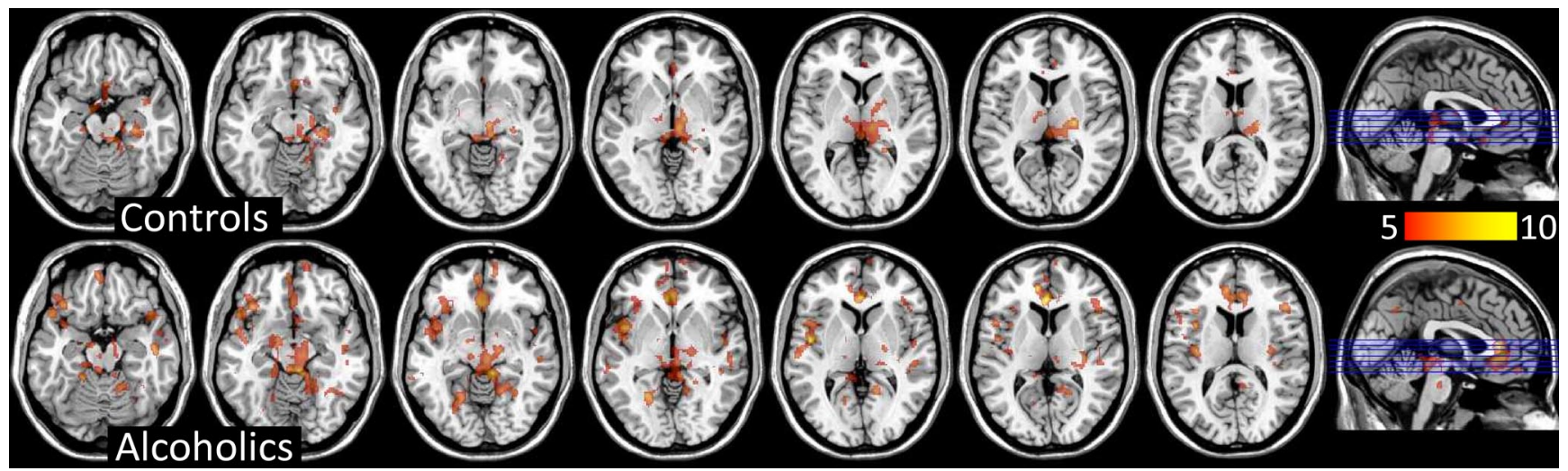

Figure 5. SPM results for the voxelwise analysis where the correlations (positive) between MP-induced changes in $B P_{N D}$ (reflecting DA increases) and regional brain metabolism (reflecting changes in brain activity) were significant for the controls and the alcoholic $\left(p_{\mathrm{u}}>0.001\right)$. Decreases in $\mathrm{BP}_{\mathrm{ND}}$ reflect $\mathrm{DA}$ increases, such that positive correlations indicate that $\mathrm{DA}$ increases are associated with decreases in metabolism. There are more extensive cortical correlations in the alcoholics than in the controls. The color scale indicates the $t$ values for the comparisons.

Table 4. Locations where the SPM voxelwise analysis showed significant correlations between MP-induced changes in $\mathrm{BP}_{\mathrm{ND}}$ and MP-induced changes in relative metabolism in controls $\left(p_{u}<0.001\right)^{a}$

\begin{tabular}{lrrrrl}
\hline Region & BA & \multicolumn{1}{c}{$x$} & $y$ & $z$ & $t$ \\
\hline Thalamus VL & & 24 & -16 & 8 & 9.73 \\
Pons & & 6 & -34 & -20 & 8.9 \\
Subthalamic & & 6 & -18 & -6 & 8.26 \\
Rectal gyrus & 25 & 2 & 20 & -14 & 8.4 \\
Parahippocampal & 28 & -10 & -4 & -16 & 6.02 \\
Rectal gyrus & 25 & 2 & 10 & -16 & 5.93 \\
Amygdala & 34 & -12 & -8 & -40 & 6.26 \\
Parahippocampal & 28 & -20 & 2 & -30 & 5.57 \\
Parahippocampal & 36 & -26 & -2 & -34 & 5.12 \\
ACC & 24 & -8 & 26 & 14 & 5.72 \\
ACC & 24 & 6 & 4 & 26 & 5.14 \\
ACC & 24 & 0 & 32 & 16 & 4.88
\end{tabular}

${ }^{a}$ Corresponding BA and MNI coordinates ( $x$, right left; $y$, anterior posterior; $z$, superior inferior) and the $t$ values of the correlations.

VL, Ventrolateral.

decreases in BOLD signal in ventral striatum after cocaine administration in cocaine abusers (Breiter et al., 1997; Kufahl et al., 2005, 2008). Combined, these findings suggest that stimulant drugs decrease striatal activity in the human brain and may also reduce activity in amygdala and OFC. However, others have reported no effects of cocaine on caudate or putamen (Kufahl et al., 2005), or reductions in putamen and increases in caudate (Risinger et al., 2005; Kufahl et al., 2008). The reason(s) for these discrepancies are unclear and may relate to regional differences in sensitivity and dynamics of the responses to stimulant drugs.

Different from humans, in the rat, DA agonists increase striatal metabolism (most studies), whereas DA receptor antagonists decrease striatal metabolism (Mandeville et al., 2011). The differences in the striatal metabolic response to DA agonists between humans and rats have been hypothesized to reflect a predominance of D1R (excitatory) over D2R (inhibitory) in rats, in contrast to a predominance of D2R over D1R in humans and nonhuman primates (Mandeville et al., 2011).

In alcoholics, MP-induced metabolic decreases in ventral striatum, OFC, and amygdala were more extensive than in controls despite their attenuated DA increases, which is consistent with prior imaging studies identifying these as regions that were impaired in alcoholics (Makris et al., 2008). Although the effects of MP were reported as more aversive in alcoholics than in controls, the correlation between the regional metabolic changes and
Table 5. Locations where the SPM voxelwise analysis showed significant correlations between MP-induced changes in $\mathrm{BP}$ D and MP-induced changes in relative metabolism in alcoholics $\left(p_{u}<0.001\right)^{a}$

\begin{tabular}{|c|c|c|c|c|c|}
\hline Region & $\mathrm{BA}$ & $x$ & $y$ & $z$ & $t$ \\
\hline Parahippocampal & 36 & 30 & 0 & -32 & 13.91 \\
\hline Insula & 48 & -46 & -6 & 4 & 11.58 \\
\hline Lingual & 27 & 8 & -36 & -8 & 11.1 \\
\hline Pons & & -2 & -32 & -12 & 7.81 \\
\hline $\mathrm{ACC}$ & 24 & -2 & 34 & 10 & 10.93 \\
\hline Medial OFC & 11 & 0 & 38 & -2 & 8.53 \\
\hline Medial OFC & 11 & -2 & 30 & -6 & 8.06 \\
\hline $\mathrm{ACC}$ & 24 & 10 & 28 & 18 & 10.48 \\
\hline $\mathrm{ACC}$ & 32 & 8 & 36 & 20 & 9.04 \\
\hline Cerebellum & & -14 & -30 & -24 & 10.28 \\
\hline Insula & 48 & -44 & 6 & 0 & 8.32 \\
\hline Insula & 48 & -36 & -16 & 14 & 7.67 \\
\hline Lateral OFC & 45 & 48 & 20 & -20 & 7.59 \\
\hline Lateral OFC & 45 & 48 & 24 & 10 & 7.55 \\
\hline Frontal & 47 & 40 & 30 & 4 & 4.97 \\
\hline SMA & 6 & 2 & -2 & 48 & 7.49 \\
\hline SMA & 6 & 10 & 0 & 54 & 4.77 \\
\hline Precuneus & 7 & 2 & -66 & 40 & 7.23 \\
\hline Cuneus & 23 & 6 & -68 & 26 & 5.47 \\
\hline DLPFC & 9 & 6 & 52 & 38 & 6.59 \\
\hline Medial frontal & 10 & 8 & 58 & 32 & 6.16 \\
\hline Middle frontal & 46 & 26 & 54 & 32 & 5.35 \\
\hline Middle OFC & 11 & 8 & 68 & -14 & 6.59 \\
\hline Middle OFC & 11 & 12 & 58 & -6 & 6.34 \\
\hline Medial frontal & 10 & 6 & 64 & 20 & 5.79 \\
\hline Fusiform & 20 & 40 & -28 & -26 & 6.39 \\
\hline Cerebellum & & 30 & -42 & -30 & 5.93 \\
\hline
\end{tabular}

${ }^{a}$ Corresponding BA and MNI coordinates ( $x$, right left; $y$, anterior posterior; $z$, superior inferior) and the $t$ values of the correlations.

SMA, Supplementary motor area; DLPFC, dorsolateral prefrontal cortex.

the behavioral effects was not significant, so we cannot establish their contribution to this aversive response.

Correlation between MP-induced $\mathrm{BP}_{\mathrm{ND}}$ and metabolic changes

To assess the effects of DA increases on brain activity, we correlated the changes induced by $\mathrm{MP}$ in $\mathrm{BP}_{\mathrm{ND}}$ with those in regional brain metabolism. These correlations showed a positive association, which indicates that, in the human brain, DA increases triggered by intravenous $\mathrm{MP}$ (seen as decreases in $\mathrm{BP}_{\mathrm{ND}}$ ) are associated with decreases in metabolic activity in subcortical re- 

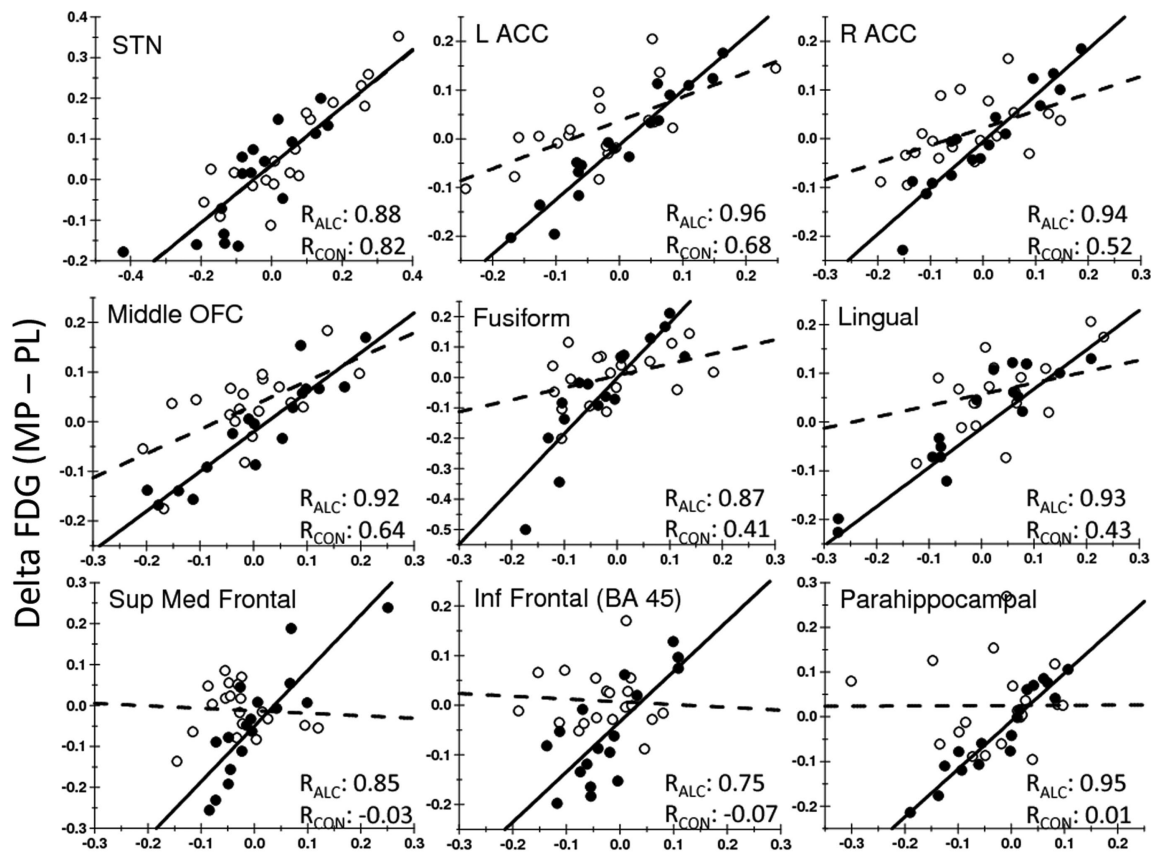

$$
\text { Delta } \mathrm{BP}_{\mathrm{ND}}(\mathrm{MP}-\mathrm{PL})
$$

Figure 6. Regression plots for the controls and the alcoholics for the correlation between MP-induced changes in $B P_{N D}$ and changes in relative metabolism. The negative values for $\triangle B P_{N D}$ reflect lower $B P_{N D}$ measures with $M P$ (i.e., DA increases with MP), and negative $\triangle F D G$ reflect lower values with MP (decreased metabolism with MP). Open symbols and dashed lines represent controls; and closed symbols and continuous lines represent alcoholics. STN, Subthalamic nucleus; L, left; R, right; Sup, superior; Inf, inferior.

Table 6. Locations where SPM voxelwise correlations between MP-induced changes in $\mathrm{BP}_{\mathrm{ND}}$ and changes in regional metabolism were significantly greater for alcoholics than controls ${ }^{a}$

\begin{tabular}{lrrrclc}
\hline & $x$ & $y$ & $z$ & Controls $(r)$ & Alcoholic $(r)$ & $F, p$ \\
\hline LACC & -2 & 34 & 10 & 0.68 & 0.96 & $13, p<0.0001$ \\
RACC & 10 & 28 & 18 & 0.52 & 0.94 & $8, p<0.001$ \\
RACC & 8 & 36 & 20 & 0.46 & 0.93 & $9, p<0.0001$ \\
Inferior frontal BA 45 & 48 & 24 & 10 & 0.43 & 0.87 & $9, p<0.0001$ \\
Inferior frontal BA 45 & 40 & 30 & 4 & -0.07 & 0.75 & $12, p<0.0001$ \\
SMA BA 6 & 10 & 0 & 54 & 0.31 & 0.76 & $8, p<0.002$ \\
Superior medial Frontal & 6 & 52 & 38 & 0.07 & 0.81 & $11, p<0.0001$ \\
& 8 & 58 & 32 & -0.06 & 0.85 & $13, p<0.0001$ \\
Middle 0FC & 8 & 68 & -14 & 0.64 & 0.92 & $7, p<0.004$ \\
Fusiform & 40 & -28 & -26 & 0.41 & 0.87 & $9, p<0.0001$ \\
Lingual & 8 & -36 & -8 & 0.43 & 0.93 & $10, p<0.0001$ \\
Parahippocampal & 30 & 0 & -32 & 0.01 & 0.95 & $10, p<0.0001$ \\
Precuneus & 2 & -66 & 40 & -0.02 & 0.79 & $8, p<0.002$ \\
\hline
\end{tabular}

${ }^{a}$ MNI coordinates ( $x$, right left; $y$, anterior posterior; $z$, superior inferior), the correlation values $(r)$ for the controls and the alcoholics, and the $F$ values for the comparisons of the correlations and their significance level $(p)$. None of the correlations in controls was greater than in alcoholics.

$L$, Left; R, right; SMA, supplementary motor area.

gions, ACC, rectal gyrus, and parahippocampal gyrus. The results from these correlations are also consistent with an inhibitory effect of DA, mediated by D2R (presumably also D3R) in the human brain.

Interestingly, the correlations with metabolism were observed in cortical and subcortical regions that have relatively low levels of $\mathrm{D} 2 \mathrm{R}$, whereas the correlation in striatum, which is the region with the highest D2R levels, was not significant. This is likely to reflect the fact that changes in regional metabolism after stimulation predominantly reflect activity in terminals and not in the cell body (Schwartz et al., 1979). Thus, the strength of the corre- lation between D2R and metabolism in a given region would not just be a function of D2R levels but of the relative predominance of D2R-expressing projection neurons, which would affect metabolism downstream, versus that of D2Rexpressing interneurons, which would affect metabolism locally. Therefore, the lack of a correlation in striatum suggests that the decreases in metabolism induced by MP predominantly reflect the changes in activity of terminals (presumably from dopaminergic stimulation) projecting into the striatum (i.e., cortex, thalamus, or midbrain). In contrast, the correlation in cortical and subcortical regions could reflect the modulatory role that D2R-expressing interneurons have on local activity (Gorelova et al., 2002).

In alcoholics, the correlations were significantly stronger and the slopes steeper than in controls, such that MP-induced DA increases (which were attenuated in alcoholics) were associated with greater reductions in cortical and subcortical metabolism (which were enhanced in alcoholics). Interestingly, regions that showed stronger correlations in the alcoholics are ones that show relatively high levels of D3R mRNA expression and D3R levels (ACC and rectal gyrus) (Suzuki et al., 1998; Tupala et al., 2003) and thus could reflect sensitized responses to D3R stimulation. However, they could also reflect an impaired modulation of DA signaling. For example, decreases in inhibitory GABAergic signaling in alcoholism (Kumar et al., 2009) could result in reduced GABA modulation of DA signaling, allowing for the stronger correlations. Indeed, alcoholics compared with controls show decreased metabolic responses to the GABAergic enhancing drug lorazepam as measured with PET and FDG (Volkow et al., 1993a), decreased GABA concentration as measured with MRS (Behar et al., 1999), and decreased GABA-benzodiazepine receptor levels as measured with SPECT (Lingford-Hughes et al., 1998). However, glutamate or other neurotransmitters (i.e., serotonin), which are also impaired in alcoholism (Ridge et al., 2008; Nishikawa et al., 2009), could also contribute to the impaired modulation of DA signaling in alcoholics.

\section{Limitations}

The specific to nonspecific binding ratio for $\left[{ }^{11} \mathrm{C}\right]$ raclopride in extrastriatal regions is low, so we cannot exclude the possibility that changes in OFC and amygdala reflect nonspecific binding. Although prior studies had used $\left[{ }^{11} \mathrm{C}\right]$ raclopride to measure D2/ D3R availability in extrastriatal regions in disease (Pavese et al., 2003; Ribeiro et al., 2009; Pavese et al., 2010; Politis et al., 2011) and to assess DA changes after stimulation (Sawamoto et al., 2008; Stokes et al., 2010), more work is necessary to corroborate that $\mathrm{BP}_{\mathrm{ND}}$ decreases in extrastriatal regions reflect $\mathrm{DA}$ increases.

$\mathrm{MP}$ was given $5 \mathrm{~min}$ before $\left[{ }^{11} \mathrm{C}\right]$ raclopride, which was followed 90 min later by FDG; thus, the effect of MP on DA was measured when MP was rapidly getting into the brain, whereas the effect on metabolism was measured when MP's levels in brain had stabilized (Volkow et al., 1995). Because the initial brain 
uptake of MP (when injected intravenously) is associated with its rewarding effects, which return to baseline 20-30 min after its injection even when MP brain levels are still high (Volkow et al., 1995), the sequential administration confounds the interpretation of the relationship between the DA increases produced by $\mathrm{MP}$ and its regional brain metabolic changes. Therefore, the metabolic changes have to be interpreted as reflecting changes in activity that follow the fast DA increases induced by MP. We chose this design to avoid giving two MP doses to the subjects and having to scan them on four different days. However, despite this limitation, the design is still valid because the pharmacological effects of MP persist for at least 2-3 h (Patrick and Markowitz, 1997), which is within the time window of the FDG measures. Moreover, at $90 \mathrm{~min}$ (time of FDG injection), the concentration of MP in brain is still very high (Volkow et al., 1995). Furthermore, based on the MP plasma concentration obtained at $60 \mathrm{~min}$ $(48-52 \mathrm{ng} / \mathrm{ml})$, the predicted plasma levels at $90 \mathrm{~min}(\sim 25-30$ $\mathrm{ng} / \mathrm{ml}$ ) would have been higher than those associated with MP's therapeutic effects (6-15 ng/ml) (Patrick and Markowitz, 1997). Finally, when we measured the effects of MP 1 min after its intravenous administration, we observed a similar pattern of changes in regional brain glucose metabolism to those reported in this study, including decreases in striatal and medial OFC metabolism and increases in cerebellar metabolism (Volkow et al., 2003).

In conclusion, our findings are consistent with a predominant inhibitory effect of DA in the human brain presumably mediated by the prominence of dopamine D2/D3 receptors that is enhanced in alcoholic subjects.

\section{References}

Behar KL, Rothman DL, Petersen KF, Hooten M, Delaney R, Petroff OA, Shulman GI, Navarro V, Petrakis IL, Charney DS, Krystal JH (1999) Preliminary evidence of low cortical GABA levels in localized 1H-MR spectra of alcohol-dependent and hepatic encephalopathy patients. Am J Psychiatry 156:952-954. Medline

Breiter HC, Gollub RL, Weisskoff RM, Kennedy DN, Makris N, Berke JD, Goodman JM, Kantor HL, Gastfriend DR, Riorden JP, Mathew RT, Rosen BR, Hyman SE (1997) Acute effects of cocaine on human brain activity and emotion. Neuron 19:591-611. CrossRef Medline

Casanova R, Srikanth R, Baer A, Laurienti PJ, Burdette JH, Hayasaka S, Flowers L, Wood F, Maldjian JA (2007) Biological parametric mapping: aA statistical toolbox for multimodality brain image analysis. Neuroimage 34:137-143. CrossRef Medline

Friston K, Holmes AP, Worsley KJ, Poline JB, Frith CD, Frackowiak RSJ (1995) Statistical parametric maps in functional imaging: a general linear approach. Hum Brain Mapp 2:189-210. CrossRef

Girault JA, Greengard P (2004) The neurobiology of dopamine signaling. Arch Neurol 61:641-644. CrossRef Medline

Glantz S (2002) Primer of Biostatistics Statistical Software Program CD-ROM. New York: McGraw-Hill.

Gorelova N, Seamans JK, Yang CR (2002) Mechanisms of dopamine activation of fast-spiking interneurons that exert inhibition in rat prefrontal cortex. J Neurophysiol 88:3150-3166. CrossRef Medline

Hamilton M (1960) A rating scale for depression. J Neurol Neurosurg Psychiatry 23:56-62. CrossRef Medline

Koob GF, Bloom FE (1988) Cellular and molecular mechanisms of drug dependence. Science 242:715-723. CrossRef Medline

Kufahl PR, Li Z, Risinger RC, Rainey CJ, Wu G, Bloom AS, Li SJ (2005) Neural responses to acute cocaine administration in the human brain detected by fMRI. Neuroimage 28:904-914. CrossRef Medline

Kufahl P, Li Z, Risinger R, Rainey C, Piacentine L, Wu G, Bloom A, Yang Z, Li SJ (2008) Expectation modulates human brain responses to acute cocaine: a functional magnetic resonance imaging study. Biol Psychiatry 63:222-230. CrossRef Medline

Kumar S, Porcu P, Werner DF, Matthews DB, Diaz-Granados JL, Helfand RS, Morrow AL (2009) The role of GABA(A) receptors in the acute and chronic effects of ethanol: a decade of progress. Psychopharmacology (Berl) 205:529-564. CrossRef Medline
Lingford-Hughes AR, Acton PD, Gacinovic S, Suckling J, Busatto GF, Boddington SJ, Bullmore E, Woodruff PW, Costa DC, Pilowsky LS, Ell PJ, Marshall EJ, Kerwin RW (1998) Reduced levels of GABAbenzodiazepine receptor in alcohol dependency in the absence of grey matter atrophy. Br J Psychiatry 173:116-122. CrossRef Medline

Logan J, Fowler JS, Volkow ND, Wolf AP, Dewey SL, Schlyer DJ, MacGregor RR, Hitzemann R, Bendriem B, Gatley SJ (1990) Graphical analysis of reversible radioligand binding from time-activity measurements applied to [N-11C-methyl]-(-)-cocaine PET studies in human subjects. J Cereb Blood Flow Metab 10:740-747. CrossRef Medline

Lyons D, Friedman DP, Nader MA, Porrino LJ (1996) Cocaine alters cerebral metabolism within the ventral striatum and limbic cortex of monkeys. J Neurosci 16:1230-1238. Medline

Makris N, Oscar-Berman M, Jaffin SK, Hodge SM, Kennedy DN, Caviness VS, Marinkovic K, Breiter HC, Gasic GP, Harris GJ (2008) Decreased volume of the brain reward system in alcoholism. Biol Psychiatry 64:192-202.

Mandeville JB, Choi JK, Jarraya B, Rosen BR, Jenkins BG, Vanduffel W (2011) fMRI of cocaine self-administration in macaques reveals functional inhibition of basal ganglia. Neuropsychopharmacology 36:1187-1198. CrossRef Medline

Mukherjee J, Christian BT, Narayanan TK, Shi B, Collins D (2005) Measurement of d-amphetamine-induced effects on the binding of dopamine D-2/D-3 receptor radioligand, $18 \mathrm{~F}$-fallypride in extrastriatal brain regions in non-human primates using PET. Brain Res 1032:77-84. CrossRef Medline

Narendran R, Frankle WG, Mason NS, Rabiner EA, Gunn RN, Searle GE, Vora S, Litschge M, Kendro S, Cooper TB, Mathis CA, Laruelle M (2009) Positron emission tomography imaging of amphetamine-induced dopamine release in the human cortex: a comparative evaluation of the high affinity dopamine D2/D3 radiotracers [11C]FLB 457 and [11C]fallypride. Synapse 63:447-461. CrossRef Medline

Nishikawa M, Diksic M, Sakai Y, Kumano H, Charney D, Palacios-Boix J, Negrete J, Gill K (2009) Alterations in brain serotonin synthesis in male alcoholics measured using positron emission tomography. Alcohol Clin Exp Res 33:233-239. CrossRef Medline

Patrick K, Markowitz J (1997) Pharmacology of methylphenidate, amphetamine enantiomers and pemoline in attention-deficit hyperactivity disorder. Hum Psychopharmacol 12:527-546. CrossRef

Pavese N, Andrews TC, Brooks DJ, Ho AK, Rosser AE, Barker RA, Robbins TW, Sahakian BJ, Dunnett SB, Piccini P (2003) Progressive striatal and cortical dopamine receptor dysfunction in Huntington's disease: a PET study. Brain 126:1127-1135. CrossRef Medline

Pavese N, Politis M, Tai YF, Barker RA, Tabrizi SJ, Mason SL, Brooks DJ, Piccini P (2010) Cortical dopamine dysfunction in symptomatic and premanifest Huntington's disease gene carriers. Neurobiol Dis 37:356361. CrossRef Medline

Phelps ME, Huang SC, Hoffman EJ, Selin C, Sokoloff L, Kuhl DE (1979) Tomographic measurement of local cerebral glucose metabolic rate in humans with (F-18)2-fluoro-2-deoxy-D-glucose: validation of method. Ann Neurol 6:371-388. CrossRef Medline

Politis M, Pavese N, Tai YF, Kiferle L, Mason SL, Brooks DJ, Tabrizi SJ, Barker RA, Piccini P (2011) Microglial activation in regions related to cognitive function predicts disease onset in Huntington's disease: a multimodal imaging study. Hum Brain Mapp 32:258-270. CrossRef Medline

Ribeiro MJ, Thobois S, Lohmann E, du Montcel ST, Lesage S, Pelissolo A, Dubois B, Mallet L, Pollak P, Agid Y, Broussolle E, Brice A, Remy P (2009) A multitracer dopaminergic PET study of young-onset parkinsonian patients with and without parkin gene mutations. J Nucl Med 50: 1244-1250. CrossRef Medline

Riccardi P, Li R, Ansari MS, Zald D, Park S, Dawant B, Anderson S, Doop M, Woodward N, Schoenberg E, Schmidt D, Baldwin R, Kessler R (2006) Amphetamine-induced displacement of [18F] fallypride in striatum and extrastriatal regions in humans. Neuropsychopharmacology 31:10161026. CrossRef Medline

Ridge JP, Ho AM, Innes DJ, Dodd PR (2008) The expression of NMDA receptor subunit mRNA in human chronic alcoholics. Ann N Y Acad Sci 1139:10-19. CrossRef Medline

Risinger RC, Salmeron BJ, Ross TJ, Amen SL, Sanfilipo M, Hoffmann RG, Bloom AS, Garavan H, Stein EA (2005) Neural correlates of high and craving during cocaine self-administration using BOLD fMRI. Neuroimage 26:1097-1108. CrossRef Medline 
Sawamoto N, Piccini P, Hotton G, Pavese N, Thielemans K, Brooks DJ (2008) Cognitive deficits and striato-frontal dopamine release in Parkinson's disease. Brain 131:1294-1302. CrossRef Medline

Schwartz WJ, Smith CB, Davidsen L, Savaki H, Sokoloff L, Mata M, Fink DJ, Gainer H (1979) Metabolic mapping of functional activity in the hypothalamo-neurohypophysial system of the rat. Science 205:723-725. CrossRef Medline

Shotbolt P, Tziortzi AC, Searle GE, Colasanti A, van der Aart J, Abanades S, Plisson C, Miller SR, Huiban M, Beaver JD, Gunn RN, Laruelle M, Rabiner EA (2012) Within-subject comparison of [(11)C]-(+)-PHNO and $[(11) \mathrm{C}]$ raclopride sensitivity to acute amphetamine challenge in healthy humans. J Cereb Blood Flow Metab 32:127-136. CrossRef Medline

Slifstein M, Kegeles LS, Xu X, Thompson JL, Urban N, Castrillon J, Hackett E, Bae SA, Laruelle M, Abi-Dargham A (2010) Striatal and extrastriatal dopamine release measured with PET and $[(18) F]$ fallypride. Synapse 64:350-362. CrossRef Medline

Sokoloff L, Reivich M, Kennedy C, Des Rosiers MH, Patlak CS, Pettigrew KD, Sakurada O, Shinohara M (1977) The $\left[{ }^{14} \mathrm{C}\right]$ deoxyglucose method for the measurement of local cerebral glucose utilization: theory, procedure, and normal values in the conscious and anesthetized albino rat. J Neurochem 28:897-916. CrossRef Medline

Srinivas NR, Hubbard JW, Quinn D, Korchinski ED, Midha KK (1991) Extensive and enantioselective presystemic metabolism of dl-threomethylphenidate in humans. Prog Neuropsychopharmacol Biol Psychiatry 15:213-220. CrossRef Medline

Stokes PR, Egerton A, Watson B, Reid A, Breen G, Lingford-Hughes A, Nutt DJ, Mehta MA (2010) Significant decreases in frontal and temporal [11C]raclopride binding after THC challenge. Neuroimage 52:1521-1527. CrossRef Medline

Suzuki M, Hurd YL, Sokoloff P, Schwartz JC, Sedvall G (1998) D3 dopamine receptor mRNA is widely expressed in the human brain. Brain Res 779:58-74. CrossRef Medline

Treadway MT, Buckholtz JW, Cowan RL, Woodward ND, Li R, Ansari MS, Baldwin RM, Schwartzman AN, Kessler RM, Zald DH (2012) Dopaminergic mechanisms of individual differences in human effort-based decision-making. J Neurosci 32:6170-6176. CrossRef Medline

Tupala E, Hall H, Mantere T, Räsänen P, Särkioja T, Tiihonen J (2003) Dopamine receptors and transporters in the brain reward circuits of type 1 and 2 alcoholics measured with human whole hemisphere autoradiography. Neuroimage 19:145-155. CrossRef Medline

Van Essen DC, Glasser MF, Dierker DL, Harwell J, Coalson T (2012) Parcellations and hemispheric asymmetries of human cerebral cortex analyzed on surface-based atlases. Cereb Cortex 22:2241-2262. CrossRef Medline

Volkow ND, Wang GJ, Hitzemann R, Fowler JS, Wolf AP, Pappas N, Biegon A, Dewey SL (1993a) Decreased cerebral response to inhibitory neurotransmission in alcoholics. Am J Psychiatry 150:417-422. Medline

Volkow ND, Fowler JS, Wang GJ, Dewey SL, Schlyer D, MacGregor R, Logan J, Alexoff D, Shea C, Hitzemann R (1993b) Reproducibility of repeated measures of carbon-11-raclopride binding in the human brain. J Nucl Med 34:609-613. Medline

Volkow ND, Wang GJ, Fowler JS, Logan J, Schlyer D, Hitzemann R, Lieberman J, Angrist B, Pappas N, MacGregor R (1994) Imaging endogenous dopamine competition with [11C]raclopride in the human brain. Synapse 16:255-262. CrossRef Medline
Volkow ND, Ding YS, Fowler JS, Wang GJ, Logan J, Gatley JS, Dewey S, Ashby C, Liebermann J, Hitzemann R (1995) Is methylphenidate like cocaine? Studies on their pharmacokinetics and distribution in the human brain. Arch Gen Psychiatry 52:456-463. CrossRef Medline

Volkow ND, Wang GJ, Fowler JS, Logan J, Angrist B, Hitzemann R, Lieberman J, Pappas N (1997) Effects of methylphenidate on regional brain glucose metabolism in humans: relationship to dopamine D2 receptors. Am J Psychiatry 154:50-55. Medline

Volkow ND, Wang GJ, Fowler JS, Gatley SJ, Logan J, Ding YS, Hitzemann R, Pappas N (1998) Dopamine transporter occupancies in the human brain induced by therapeutic doses of oral methylphenidate. Am J Psychiatry 155:1325-1331. Medline

Volkow ND, Wang GJ, Fowler JS, Logan J, Franceschi D, Maynard L, Ding YS, Gatley SJ, Gifford A, Zhu W, Swanson JM (2002) Relationship between blockade of dopamine transporters by oral methylphenidate and the increases in extracellular dopamine: therapeutic implications. Synapse 43: 181-187. CrossRef Medline

Volkow ND, Wang GJ, Ma Y, Fowler JS, Zhu W, Maynard L, Telang F, Vaska P, Ding YS, Wong C, Swanson JM (2003) Expectation enhances the regional brain metabolic and the reinforcing effects of stimulants in cocaine abusers. J Neurosci 23:11461-11468. Medline

Volkow ND, Wang GJ, Telang F, Fowler JS, Logan J, Jayne M, Ma Y, Pradhan K, Wong C (2007a) Profound decreases in dopamine release in striatum in detoxified alcoholics: possible orbitofrontal involvement. J Neurosci 27:12700-12706. CrossRef Medline

Volkow ND, Wang GJ, Newcorn J, Telang F, Solanto MV, Fowler JS, Logan J, Ma Y, Schulz K, Pradhan K, Wong C, Swanson JM (2007b) Depressed dopamine activity in caudate and preliminary evidence of limbic involvement in adults with attention-deficit/hyperactivity disorder. Arch Gen Psychiatry 64:932-940. CrossRef Medline

Volkow ND, Wang GJ, Fowler JS, Tomasi D (2012) Addiction circuitry in the human brain. Annu Rev Pharmacol Toxicol 52:321-336. CrossRef Medline

Wang GJ, Volkow ND, Roque CT, Cestaro VL, Hitzemann RJ, Cantos EL, Levy AV, Dhawan AP (1993) Functional importance of ventricular enlargement and cortical atrophy in healthy subjects and alcoholics as assessed with PET, MR imaging, and neuropsychologic testing. Radiology 186:59-65. Medline

Wang GJ, Volkow ND, Hitzemann RJ, Wong C, Angrist B, Burr G, Pascani K, Pappas N, Lu A, Cooper T, Ja L (1997) Behavioral and cardiovascular effects of intravenous methylphenidate in normal subjects and cocaine abusers. Eur Addict Res 3:49-54. CrossRef

Wang GJ, Volkow ND, Fowler JS, Logan J, Pappas NR, Wong CT, Hitzemann RJ, Netusil N (1999) Reproducibility of repeated measures of endogenous dopamine competition with [11C]raclopride in the human brain in response to methylphenidate. J Nucl Med 40:1285-1291. Medline

Wang GJ, Smith L, Volkow ND, Telang F, Logan J, Tomasi D, Wong CT, Hoffman W, Jayne M, Alia-Klein N, Thanos P, Fowler JS (2012) Decreased dopamine activity predicts relapse in methamphetamine abusers. Mol Psychiatry 17:918-925. CrossRef Medline

West AR, Grace AA (2002) Opposite influences of endogenous dopamine D1 and D2 receptor activation on activity states and electrophysiological properties of striatal neurons: studies combining in vivo intracellular recordings and reverse microdialysis. J Neurosci 22:294-304. Medline 